\title{
Naming Our Child
}

\author{
Marie Laing \\ University of Alberta
}

What terrible names

Are Jamie and James

Thought Jim.

"Peter is sweeter

And Patrick is neater"

But when he was christened

Nobody listened to him.

(Robert Wesley-Smith)

What is in a name? I think my name; I think the names of those I know and love, the images that the sounds form speak to me: the memories and the definitions come to mind. Is my name, is any name an arbitrary label chosen at random, or is a name a calling, a calling forth of an archetypal image that resonates through time? Can a name without a past have meaning? I ask, "By what authority is my name mine and yours thine?" Could yours be mine and mine yours? William Shakespeare said, "That which they call a rose, By any other name would smell as sweet." But could we call a rose a petunia? Or a canary a magpie? Or a magpie a rose? Indeed, is it as Gertrude Stein says, "A rose is a rose is a rose?" By any other name would I be me, would you be thee? And how was it that my name was chosen for me and yours for you?

\section{Naming the World}

As children, our earliest activities involve coming to know and to name our world. We know and name that which is important and ignore and do not cognize that which is unimportant. The word, the name, allows us to re-cognize that which is named and to come to know it better. The name is the center of a constellation of meanings and images that come to reveal the uniqueness and the essence which constitutes that which is named. Thus, "Daddy" comes to mean a male person who cuddles me, reads to me, comforts me, puts me to bed, and awakens me but who does not deliver the mail or drive a transit bus.

In the beginning, the child is part of a world of shared names and shared meanings. But then the child receives a doll, a kitten, or a puppy and is allowed to name it. Sometimes the name chosen is simply "Dolly," "Kitty," "Puppie," or it may be named after a loved relative or friend, or a TV character, and the name chosen may be "Mollie," "Garfield," or "Snoopy." As we, as children, grow older, 
choosing a name is more difficult. It may be chosen to reflect a special way of being and the result is names such as "Trixie," "Mozart," or "Fred." Should any helpful but unsuspecting other, mother, father, brother, or sister (who does not know that choosing a name is a personal matter), give a suggestion, that person will be told, "It is mine, and I get to name it." Young girls dreaming the age-old dream of becoming mothers of children play at naming their future babies, "If I have a boy, it will be Phillip George; if a girl, Elizabeth Mary." "Not me, I like...." And lists of names are made and kept for future reference when a real baby is to be named.

In school, students are requested to write term papers that must have titles. In the first years, the unenthusiastic student may produce a treatise named, "Changes in Society in Georgia Before, During, and After the Civil War," a far cry from the title of the book on the same subject matter, a book called Gone With the Wind. The creative author, the artist, tries to capture the essence of what is written and to communicate the many levels of meaning. It is as if the "right" title emerges from the work-the creative process and the creation-itself and speaks to its author and through its author to those who will read it. Some titles eloquently state the essence of a book. And No Birds Sang is a book about World War II. The title conveys a world view, a constellation of meaning, and an understanding. It encapsulates the meaning of the book in four words and it speaks to the heart.

\section{Choosing a Name}

To name one's own child is to name a part of the world, a part that is our creation. It is to name a part of us even as that part begins to become separate from us. Naming often begins before the child is conceived, when she is but a dream of the future, when we are still children dreaming of when we will be big. And when we marry, with our partners we plan our family, "a boy, and then a girl," and we create lists of names we like, names we will bestow upon our children as gifts, perfect names to mark our children's uniqueness and specialness, names that capture our vision of their future, names we may never use, "I dearly love the name 'Michael.' Each pregnancy, it faithfully goes on the list but with three children, I still have not attracted a soul who needs the vibration of the name 'Michael' " (Forhmzway, 1977, p. 17). And we feel a thrill of anticipation and power. Now we are big and, like Adam before us, will name a part of the universe; we will name our creation. It is ours to do by right, to name this child that will be ours.

Then, as a woman, as a mother to be, I feel my unborn child move within me, and we must choose a name, a name that will last a lifetime. We know that this is more serious than the dreams and the plans: this is real. We seek the "right" name, because this name will 
be the focal point for our child's uniqueness, for her very existence as a separate being for others as they come to create their images of her, as they come to "know" her. And she comes to have meaning for them in her subjectivity, a subjectivity symbolized and fused with her name: "Oh, that's just Ethel being Ethel," a name that is more than a label.

Parents taken with the child's distinctness may set the child apart through choosing unusual names, such as Arabella or Lucas, or through choosing unusual spellings (in English) for names such as Coreen or Jeanne. Parents centered on the child as their own creation may invent a name: "This child is our creation, therefore the name for this child must be our creation." Such names may be invested with a secret significance like a magic potion, "a mixture of significantly secret ingredients" (Dunkling, 1982, p. 15). Parents preoccupied with the exotic may choose names like Lotus Blossom or Apollo. Other parents caught in the moment may choose names such as Dewdrop or Starsky, names without a history through time, names without resonance that fall with a thud in the present. The names so chosen capture the parents' perspective of the child and may influence in many ways that which the child becomes: "In my experience people with unusual Christian names have personalities to match" (Dunkling, 1982, p. 12). Such names may be hard to pronounce and spell, to communicate and to remember, so that the child is burdened by the name, unable to convey or make it understood, "I have been fractioned by it, the way people defined me by what they could handle. I felt submissive-call me what you canand apologetic for such a difficult name" and may withdraw, "I have come to prize my name even though I believe it contributed to my introverted nature with some undertones of arrogance and uniqueness."

But even as we choose a name to set our child apart, we may choose a name that links our child to our family, to some admired loved one, to our past. We may attempt to forge a bond through time with the name, or to bestow on the future the riches of the past. In other places and other times, the link with the past was legitimized through tradition. Family names were passed from father to son, from mother to daughter; early Christian names were limited by law as well as tradition to Biblical or sainted names as a way of calling forth divine virtue, protection, and guidance. Today, tradition or family may suggest what names are appropriate. The choice by the parents will indicate the power of that influence. They may knowingly risk offending or hurting a beloved father by not naming their son, his first grandson, after him. They may grudgingly "use" the family name, or they may gladly and freely choose to name the child after him.

The belief in the power of the name to bestow on the bearer special qualities is exemplified by totemistic names-Bernard means bold 
as a bear, and Adolph means noble wolf-and underlies the attraction of books of names that list what the names mean and books on numerology: "Each man's fortune is written in his name, as astrologians say all things are written in heaven, if a man could read them" (Camden in Dunkling, 1982, p. 81). In naming our child after an admired person, we may hope that the child will be like that person: "It would have to be a name rich with history and with promise, for the people of his tribe ... believed that a child would develop seven of the characteristics of whomever or whatever he was named for" (Haley in Dunkling, 1982, p. 6), or "It was my father's choice. He thought she was a conscious woman." However, we may avoid certain names if we hold that they have been contaminated with the unpleasant characteristics of a person of that name: "I wouldn't name a child Waldo, I knew a Waldo once and he was stupid" or "She's just like her mother, even has the same name" as if the name compounds the traits carried by the genes. In more rational times, parents, who wish their child to be the recipient of another's wealth or love, may name the child after that person. Few of us can resist feeling pleased about and connected to a child who bears our name; such is our psychic connection with our name and our namesake.

We may be honoring that person whose name we choose for our child for in honoring the name, we honor the person who is one with the name, a oneness that is acknowledged when we ask permission to "give" the name to our child, a oneness felt so that when we reveal our name to another, we feel we have revealed our very self. We feel vulnerable for that person can now "know" us and use the power of our name against us; a oneness of name and spirit so that in keeping alive the name, we hope that the spirit of the other may live on: "'You're named after me,' he said, 'and that's quite a responsibility because when I'm gone, I'll still be here in you. Take good care of that name, son'" (Gordon in Dunkling, 1982, p. 7). And the child may spend a lifetime living up to a "father's good name," the name which has become the spirit incarnate. Thus, we try to overcome human mortality for as the name "lives" on through the generations, it becomes a thing-in-itself, a continuous thread of human existence: "I live on through my children" or "If he has no sons to carry on his name, his name will die." It is as if something will be lost when that name dies, a connection through time broken, a magical connection marked by a name, a connection that "stands out," that exists, that is, that is "known" because it is "named": "I can trace my ancestry back to the Norman invasion." A connection that is passed like valued property, from father to son, like a sacred trust. In naming a child after a relative who has recently died, parents may hope to "call" back the spirit of that person for those who grieve, "I did it, [named my daughter after a dead sister] to give them [my parents] back a semblance of their daughter, it was a gift to them." It is a gift that denies the child's uniqueness, "it's like wishing a piece of some- 
one different onto a new person" (McCullough in Dunkling, 1982, p. 8). It is as if we must, at once, deny and transcend our fate and our immediate lifetime, to be in touch with that which has come before us and that which will come after; the name is a link or a bridge between the temporal and the eternal. It is as if we need to experience our participation in that which endures, that which is Being.

There is another way in which we may wish to choose the "right" name for our child, a name for her uniqueness, a name that "calls" forth her spirit: "I would have called myself something that would have allowed the gypsy to emerge." The name allows her to capture images of herself as she develops a sense of her self as separate from her parents, her family, her world, as she comes to know herself objectively in her essence: "I am Ronalee, I am Woman, Yes, I am shouting, I just want to $B e$." A name symbolizes for her, as well as for others, her "being," that which endures through the years as she is seven, seventeen, and seventy, her very being as a part of Being, that which endures through all time.

But her name is more than an arbitrary sign that points to her, more than an image or a constellation of meaning. For our child we seek the "right" name, a name that reflects not a conventional relationship to our child but Plato's natural and necessary agreement where there is a degree of correctness or a rightness about the name: "The word has a mysterious connection with what it represents, a quality of belonging to its being. This is meant in a fundamental way" (Gadamer, 1982, p. 377). Further, "I am quite a fatalist in the matter of names, believing that a mysterious correlation exists between the man and the name he bears" (Zola in Dunkling, 1982, p. 3).

We know that there are right names, names that fit: "She is a Rose." "Yes, he is a..." and we know people in whose names we sense a discordance and an incongruity. We know their names do not fit: "Yahov Ivanovitch Dologishev, he called himself but I know from the sound of it on his tongue that the name didn't fit him.... A name belongs to you as your birthright but it hung on him like a suit of stolen clothes" (Malamud in Dunkling, 1982, p. 4). Yet if we were to examine the name of the person that doesn't fit, we would be unable to determine the cause of our discomfort for "the ideality of the meaning lies in the word itself" (Gadamer, 1982, p. 377). In the adult person rightfully named, we sense the unity of the very being of the person and the name: "For even a person's ego, his very self and personality, is indissolubly linked with his name. . . It is taken as a truly substantial Being, an integral part of its bearer.... It is in the same category as his body and his soul.... And of all these three elements, it is just the last mentioned which becomes more and more the expression of a man's 'self'; of his 'personality' " (Cassirer, 1946, pp. 49-50). And so we say, "I cannot imagine you with any other name. You are a Michael." 
In other places, names were chosen as the parents developed a sense of the baby, child, person, or after an identity had been established and, in some cultures, provision is made for formally changing names that do not fit, or for changing the name as the person changes and evolves (Langer, 1942). But at this time and place in history, there is a lack of recognition of the need to find the right name, and a name must be chosen before the baby and mother leave the hospital: "Only three days to name the baby here, in England we had three weeks." For me, for us, to name a child newly born and unknown is not an easy matter. It is a process shrouded in "mystery" as we await the "right name" to come to us: "This need worked within me secretly, day and night. Fortunately, my mind was unaware; all this went on behind its back. One morning I got up and the ... name gleamed unforeseen ... in the air" (Kazantzakis, 1965, p. 469).

My sense of my children developed as they moved within me, "the football player, the runner, the thumper." But I came to know the rhythm of their "being." We, their father and I, pondered the family names, the familiar names and unusual names. We checked the dictionary list of names, we bought books of names, we were ever alert to new names or interesting names, trying them out for sound, size and the images formed: "How does Zena sound?" We'd eliminate names with negative vibrations, names that could be diminished for the diminutive diminishes the person. We made lists of names. Then, "How does this sound with this; is it better the other way round?" "That doesn't flow," "Look what the initials spell." For some parents, the choice is clear from the start: "If it's a girl, it will be Margaret after my friend, and Neil after my brother if it's a boy." For others, short lists are made and tacked up on the refrigerator: "I've always wanted a son ....," "It's been Katrina Lauren for four weeks now, but we'll see." The final choice is to be made after the baby's birth, after we come to "know" her. We want to "call" forth the essence of our child's being as it will unfold in the lifetime just beginning, as the ancient people of the past believed to speak a god's name was to risk calling forth the god in all her wondrous and aweful power. So we believe in the power of the name, but the name is also a legacy, a hope and a prayer, a magical thought to bestow on our child our vision of her future; it is a call to the future. How does our vision shape that future? We know that we must choose a name, but in choosing one possibility, we eliminate others, we cast them out: "In the beginning I could not assign ... a name, perhaps did not want to, for I knew well that a name imprisons the soul, cramps it so that it can fit inside a word, obliges it to take whatever it has of the inexpressible, all the most precious qualities for which no substitute can be found, and abandon them outside this name's boundaries" (Kazantzakis, 1965, p. 469). "She is named after her father's favorite aunt who is a mother substitute for him. The name is rather common and has the diminutive built right in. Even now, she is bigger 
than her name." Is our child like Ra of ancient mythology in whom resided many names and many shapes, whose Name resided deep within to be called forth and given form; whose being is called into separateness, egohood, existence and that existence into language? "We seek the right word, i.e., the word that really belongs to the object so that the object comes into language" (Gadamer, 1982, p. 377). And I think of the fragmented egos with many forms. I think of Eve (The Three Faces of Eve), of Sybil, of Billy Milligan (The Mind of Billy Milligan)_persons with multiple personalities - who showed so clearly the many parts in one. Each part had a name, given from within so that it could be "known" and called forth. From whence came the names, the possibility, the special "being" of each part? And we see the power of the word, the name, to create a symbolic reality more "real" than the physical reality it represents. Is our child shaped and formed in accord with her name, our image of her? We wonder. Is it that the right name, the true name, expresses the state of spiritual energy that our child embodies? Is it that we come to name our child, to "know" our child's name, through knowing her, through dialogue with her: "The soul of your child knows what it needs to fulfill its destiny. A suitable name is given to the parents through what may be termed 'idea-seeds' which are planted shortly before or after birth.... The soul of the unborn child needs that particular name.... However, if you decide on a name and stick to it, it is possible to attract a particular soul to your child" (Forhmzway, 1977, p. 17). Even as we ponder the names for our child, we know that other names will be given to her by the world, even by ourselves.

\section{The World Names Our Child}

There will be the baby names given in the early weeks and months of her life, the names that capture a tiny part of her essence, names such as "Button," "Chugger," and "Snooks," names that capture her babyness, names that will fall away as she outgrows them. Then there may come the nicknames, often by accident, a chance encounter, a glimpse that occurs in the intimacy of childhood, that survive out of the vulnerability of childhood when we have no choice but to respond to how another sees and calls us; they are a denial of the child's total personhood and as such are often resented: "I don't like cutesy names," or "I chose my children's names so no one could make nicknames out of them." In adulthood they are felt to diminish or portray the person as a child, yet they may endure, out of habit or because the caller fails to see that the child has grown into an adult, or the nickname may be used as a way of keeping her in her place, as a lesser being and not fully mature. Indeed, the adult may respond as the child she was: "without a right to say anything, and I still buy into it," or "Being called old names flips me back into an old way of being." Or such nicknames may be used to recall a past relationship or to forge surreptitiously one where none exists: "Here Didi, you 
don't mind me calling you Didi, do you? Let me show you our latest line of stoves." However, even as in primitive societies in which nicknames were given to hide or safeguard the real name which was held to contain one's spirit or essence, a person may choose a nickname to hide her real name, a name that makes her feel vulnerable and exposed or which does not convey her image of herself and Wilhelmina may become Mickey. Or she may choose to change her name completely to convey a chosen image of herself: Margaret Hookman became Dame Margot Fonteyn and Leonard Slye became Roy Rogers. She may choose a name to hide her identity as women in the past chose men's names to gain acceptance, thus Mary Ann Evans became George Eliot (Dunkling, 1982). There are the secret pet or love names not unlike the "baby" names that arise out of a "special" moment of love between two people and which may come to symbolize all that is between them. Such names, laden with meaning and emotion, are spoken only in the presence of the loved one and remain forever a reminder of their special love: "'Pongo' was his old special silly delightful name for her, and even now ... the sound of that 'Pongo' gave her a little thrill" (Priestly in Dunkling, 1982, p. 22). It is also a reminder of their vulnerability so that there is much embarrassment and consternation if the name is revealed.

The time may come when a woman accepts the honor of a man's name in marriage, an acceptance of his birthright and power as she relinquishes her own, and she may feel honored by him as she embraces a new identity and a new status: "When I took it, I felt so proud, so happy to be Mrs. Somebody instead of Spinster ..., " or "I was delirious with joy, it was like a fairy tale, one happy ever after, complete," and "I was totally unconscious and delighted, uh, wonderful." With the giving and receiving of a name, the two shall become one. But not everybody is so enthusiastic: "'You're joking,' said Meredith, aghast, 'Mrs. Meredith Jones. Jos, you'll have to change it. I can't give up Montgomery for Jones. You couldn't ask me to" " (Foster in Dunkling, 1982, p. 83). A man may feel that he honors a woman by giving her his name and may feel hurt by any rejection of it as if it is a rejection of him. But many women now refuse to give up their names, and many of those who did have come to know that in embracing the new name, the identity of another, they have lost themselves. They seek to reclaim their names and their destiny.

\section{Choosing Our Child's Name}

But we must return from the future, for this is the now, and seek the name that will come before and that will endure beyond all of the world's names. We seek her name. And then our child is born. We gaze at her, we hold her, we speak with her, "The naming of the world, which is an act of creation and re-creation, is not possible if it is not infused with love" (Freire, 1968, p. 77). So we hold our child. 
We try on the sounds; we try on the images: "Wade, soft and loving, and, I think, confident." We try to gain a sense of her, of her presence: "In fact, no reflective process operates when the word is formed for the word is not expressing the mind but the intended object" (Gadamer, 1982, p. 383). We glory in the miracle of her. She is but a tiny presence yet much more, a part of life, of all life, a human life: our hope for the future, our link with eternity. We continue to try out names. Time is running out. We talk with each other, with our children; we have family conferences around the nursery window as we behold her uniqueness, her specialness. We start to feel embarrassed when people ask, "And what is her name?" There is a sense of urgency. But we want the right name. We realize more clearly the awesomeness of the task; it is our right to name her for she is ours, but it is also our responsibility and our duty to her. We participate in the primordial task, a task that is uniquely human; nobody says, "Ah, what difference does it make?" for we know it makes a difference, a difference of which we cannot speak, a difference for all time. We feel our power and wonder why we tremble. What is this belief in the power of the word, of the name, a power more clearly understood by ancient peoples who knew the magic of the name so fused with the person that "the name functions as proxy for its bearer and to speak the name may be equal to calling a person into being"; thus, "being able to speak it bestows control of that power on the knower" (Cassirer, 1953, pp. 53-54), the caller, the one who names. This is the final act of creation.

Then it is time to fill out the forms. We write the name, her name; we try it on her one more time. We sign the forms. We have brought into being, we have named our child, for the world, for us, for herself, and for God.

In the days, the weeks, and the years that follow, I call her by name and affirm our choice even as my secret heart listens to see if it is the right name.

\section{Notes}

1. Quotes not referenced as to source are from personal interviews conducted by the author.

\section{References}

Cassirer, E. (1946). An essay on man. London: Yale University Press.

Cassirer, E. (1953). Language and myth. New York: Dover.

Dunkling, L. (1982). Our secret names. Englewood Cliffs: Prentice-Hall.

Forhmzway, A. (1977). Your destiny is in your name. Markham, Ontario: Paper Jacks.

Freire, P. (1968). Pedagogy of the oppressed. New York: Seabury Press.

Gadamer, H. (1982). Truth and method. New York: Crossroad.

Kazantzakis, N. (1965). Report to Greco. New York: Touchstone.

Langer, S. (1942). Philosophy in a new key. Cambridge: Harvard Press. 